\title{
Implementation of group activity to solve academic Burnout elementary school students
}

\author{
Muhammad Nur Wangid *, Isti Yuni Purwanti \\ Department of Educational Psychology and Guidance, Faculty of Educational Sciences, Universitas Negeri \\ Yogyakarta. Jalan Colombo No. 1, Karangmalang, Yogyakarta 55281, Indonesia \\ * Corresponding Author. E-mail: m_nurwangid@uny.ac.id
}

Received: 14 July 2020; Revised: 19 July 2020; Accepted: 29 July 2020

\begin{abstract}
Academic burnout in elementary school students is very important to note because in this elementary school all academic experience will be formed. Failure to experience education in elementary schools properly will have a wide and disparate impact on the lives of students. This study aims to reduce the academic burnout experienced by elementary school students. For this reason, collaborative action research is conducted between teachers and researchers. Collaborative research, since planning, implementing, monitoring, and evaluating, as well as reflection is carried out jointly between teachers and researchers. The study subjects were five low-grade students who showed symptoms of experiencing academic burnout. Application of group activities as actions in the form of three games for students, namely picture puzzles, serialized stories, and throwing balls. Observation and interview as the main technique in collecting data. Qualitative analysis is used to analyze the process and results of actions. The results showed that the application of group activities was effective in reducing the academic burnout of five research subjects. All students showed positive changes in behavior, no longer showing symptoms of emotional fatigue, depersonalization, and feelings of inferiority or inadequacy. Research implications and recommendations are discussed.
\end{abstract}

Keywords: group activity, academic burnout, elementary school students

How to Cite: Wangid, M., \& Purwanti, I. (2020). Implementation of group activity to solve academic Burnout elementary school students. Jurnal Prima Edukasia, 8(2), 135-144. doi:https://doi.org/10.21831/jpe.v8i2.33267

\section{Introduction}

Going to school particularly for the first time is the most desired and happiest thing for students. They will meet new friends then share each other stories, play and joke together, in which these are different experiences compared to when they are at home. On the other hand, school is not only a place for all students to fulfill their joyfulness but also to socialize. Each student meets others to find the broader meaning of life, share games that can be played at school, and learn to comply with some rules applied. They must learn to know each other, queue, being loyal, share, and so on. Thus, it needs great adjustment in them. Some students have not yet been able to fulfill these conditions quickly, thus they are left by their peers. As a result, they feel "alone" due to losing friends (Lakhani et al., 2017).

Along with joyfulness experienced by students, they start learning academic values delivered by teachers. A subject delivered by teachers may be completely diverse with what they have experienced/ learned before. Academic knowledge prioritizing rationality often is perceived as something unfamiliar (El Nokali et al., 2010). This may be caused by a student's cognitive development stage that has not yet been able to fulfill the conditions. Therefore, teachers in the low-grade class had to lead academic mastery gradually according to the student's development and step by step academic knowledge will be comprehended. Unfortunately, classical learning conducted in school frequently pays less attention to some students lagging. Thus, some students feel neglected (Wakil et al., 2017).

The cause of boredom to go to school in children is complex, in which it may not only be obtained from school but also children's unprepared mental condition is facing changes (Çam \& Öğülmüss, 2019). In general, two factors are causing academic burnout in students: internal and external factors. Internal factor is derived from student's inner self such as physical and psychic exhaustion, lack motivation in achieving achievement, etc (Rahmati, 2015; Walburg, 2014). The external factor is derived from outside 
influences such as boredom of teaching methods, friendship incompatibility, and pressure obtained from parents. Children can experience academic burnout because the school is a new society having new rules that diverse with the home. Children are asked to come to school on time, do the given tasks including homework and other tasks (Pingge \& Wangid, 2016). There is also a case when children are already old enough to go to school but they still want to be free before going to school, thus it makes them lazy to go to school (H.-J. Yang, 2004). Burnout can cause mental pressure in the form of anxiety, depression, frustration, hostility, or fright. The previous study shows that burnout can cause lower commitment, higher abstentions, lower productivity, impoliteness, and lower humanity consideration (Cordes \& Dougherty, 1993).

Academic burnout in students is pictured as happened in student's learning process when facing pressure from a new subject or other psychological factors such as emotional exhaustion, depersonalization, and perceiving low achievement (H.-J. Yang, 2004; H. Yang \& Chen, 2016).

Problems such as academic burnout experienced by elementary students can be helped by cooperation from all parties (counselors, parents, and teachers) (Crespi et al., 2006; Riva \& Haub, 2004; Shechtman, 2014). Based on this reason, there is a need for guidance service and counseling aiming to help the students in achieving self-development. Thus students can develop their talents, potentials, and interests to actualize themselves well (Yuen, 2008).

There are several techniques in guidance and counseling that can be used to help students facing the problem such as group activity, individual counseling, and group counseling (Berg et al., 2018). Following elementary students' characteristics and age, in which they start entering grouped age, thus this study tries to implement group counseling particularly in a group activity in resolving academic burnout in elementary students.

Jean Piaget stated that playing shows two realities to children: adaption to what they have known and their response towards new things (Bhagat et al., 2018). In playing facility often becomes objective. Several responses arise for the response itself. For example, the aim of student's running is not for health but for the run itself. Run is run. It is not for objectives as what is imagined or thought by adults.

Therefore, for children play is a facility to transform potential strength become various abilities and skills. Playing also can be a way to transfer excessive energy and relaxation (Ahmad et al., 2016). Thus, when children in boredom, anxiety, etc, playing or games can be an alternative to lessen the possibility of burnout in children.

\section{Method}

This study is action research. Action research makes it possible for practitioners to research and evaluate their research results everywhere (McNiff \& Whitehead, 2011). Therefore this study was conducted collaboratively among researchers and teachers or often called collaborative action research (Stringer, 2007).

\section{Research Subjects}

The subjects of this research are students of elementary school (Grades 1, 2, and 3) in SDIT Salsabila Baiturrahman Prambanan, Klaten, Central Java. The subjects were selected based on nomination conducted by teachers understanding and regularly interacting with the students. The nomination was measured based on indications of academic burnout. Therefore, the subjects were selected purposively. We obtained 5 (five) students showing indications of academic burnout. See Table 1.

Table 1. Research Subject

\begin{tabular}{cccl}
\hline No. & Age $(\mathrm{y} / \mathrm{o})$ & Grade & \multicolumn{1}{c}{ Indications } \\
\hline 1. & 6 & 1 & $\begin{array}{l}\text { Student shows laziness when given tasks, self-withdrawing, and reluctance in doing } \\
\text { the tasks and put the book into the bag to be homework. } \\
\text { 2. }\end{array}$ \\
3. & 8 & 2 & $\begin{array}{l}\text { Slow, talkative, has no responsibility, has difficulty in writing. } \\
\text { The reluctance in going to school, feeling uneasiness in school, giving blank } \\
\text { answers, not knowing the purpose of learning in school. }\end{array}$ \\
4. & 7 & 2 & $\begin{array}{l}\text { Has no understanding of right and obligation of going to school, not afraid of } \\
\text { sanctions, cannot read fluently, whim. } \\
\text { The reluctance of doing tasks, laziness, not doing daily tasks, being dependable on } \\
\text { the teacher. }\end{array}$ \\
5. & 8 & 3 &
\end{tabular}


Jurnal Prima Edukasia, 8 (2), 2020 - 137

Muhammad Nur Wangid, Isti Yuni Purwanti

\section{Research procedures}

This collaborative action research was conducted through four steps (Stringer, 2007). The first step is planning. In the planning step, identified the problems arising concerning academic burnout. To be able to identify the problem conducted several interviews with homerun teachers, headmaster, and students. Also observed students in grades 1, 2, and 3. Before the treatment the teachers and homerun teachers trained as collaborators in this study. The training given to teachers aims to give understanding regarding group counseling and academic burnout. Moreover, developed a schedule of activities, places, and times of this action research. Actions are given in group counseling with various games adjusted with expected objectives. Therefore, in the planning step planned group games that are suitable for our objectives and group counseling materials in resolving academic burnout.

The second step is implementation. In this step, we implemented the actions with collaboratorsbased on identification and planning in the first step. We implemented group counseling towards students showing academic Burnout indications. In this group counseling, used group games that are suitable for elementary school students.

The third step is observation and monitoring. With collaborators, the researcher observed, monitored, and evaluated the actions conducted in the second step. In this step, used observation, field notes, and interviews as the methods. The success indication is students go to school every day willingly without influence from parents, teachers, and the homerun teacher). The last step is analysis and reflection. With collaborators we analyzed, synthesized, and used the result of the planning step to conclude whether we needed to revise the beginning idea or rethink and make a new plan for the next action.

\section{Research Actions}

The action given to students to overcome academic burnout is to carry out group dynamics through several games, named 'Picture Puzzles', "Continuing Stories", and "Throwing the Ball". The actions were implemented for two months. The games were implemented once in two days or three times in a week. There are several steps conducted in these actions. The first is the beginning. In this step, formed the group. The method used in forming the group is the directive model from the teachers. The next step is an explanation regarding group counseling for students, including objectives and activities that will be conducted during the group activity process. The next step is the planning activities. In this step, we decided on the materials including games, objectives, targets, tools, and facilities for a group activity, assessment plan, place, and time. After that, we start to implement the activities that we had planned in the previous step. In the implementation, step formed dynamics group by explaining the rules or methods in group activity then introduce each other and express themselves. The next step in implementation is disclosing problems experienced by students in the group (academic burnout). The information is delivered through games according to objectives in solving academic burnout in each meeting of group activity continued with activity evaluation. Evaluation of group activity is more focused on the individual, social, learning development, and other things considered useful according to students. The evaluation in group activity tends to emphasize "process" that can be conducted through observation during group activity to reveal students' understanding of materials discussed before. The last steps are analysis and follow up of the assessment result of group activity. This is needed to understand students' development and implementation of group activity more. While analyzing the interesting thing emerging is the possibility of topic continuation or problem discussed before. The follow up can be conducted through the next group activity or the activity is considered sufficiently implemented and over, thus the follow up is not necessary.

Data Collection Methods

Observation, interviews, and documentation used in collecting the data. Observation is implemented to obtain data regarding the action implementation process and its result through indications emerged by students after the implementation of group activity to solve academic burnout. Observation also is conducted to know the procedures/process of activities, teachers' activities, students' activities in following, or doing the actions directed by the teachers and changes happening on students. The interview was used to expose the experiences during the implementation of the actions and the result of the implementation perceived by students and teachers. And documentation is used as supporting data. 
Jurnal Prima Edukasia, 8 (2), 2020 - 138

Muhammad Nur Wangid, Isti Yuni Purwanti

Success Indicator

To determine the success of action we determine its success indicator. In general, the success of group activity in solving academic burnout in elementary school students is when the students show a positive attitude (not being lazy to go to school). While in particular, the first success indicator is the students do not show emotional exhaustion with showing positive attitude signing with motivation in achieving achievement, willingness to go to school, and doing the tasks well. Second, students do not suffer depersonalization showed by joining their friends or caring for their surroundings. Third, students do not show low self-esteem and easily giving up (Walburg, 2014).

Data Analysis Technique

We used the interactive analysis technique qualitatively. It includes data presentation, data reduction, and data conclusion. We considered using this technique to see and picture the success rate of group activity in solving academic burnout in elementary school students.

\section{Result and Discussion}

Result

This study was carried out in SDIT Salsabila Baiturrahman Prambanan, Klaten, Central Java. The reason for choosing this school is obtained from complaints delivered by the teachers and headmaster explaining that several students show academic burnout indications. They are lethargic to go to school, showing low-performance motivation, unwillingness in doing their tasks, and disturbing their friends (even not wanting to join their friends).

No action is taken to solve this problem, up until now. The headmaster says:

"Our school is open for anyone intending to do any activity (either it is training, research, etc). Because up until now there has not been any action or activity carried out to help our students."

A similar thing also is stated by one of the teachers (homerun teacher of grade 1):

"It's true that there has not been any activity carried out in helping our students. Nevertheless, our students are different from students studying in-state schools."

Based on these statements we were given a chance to carry out group activity in solving academic burnout of low-grade students. We chose students in low grade as our research subjects based on several complaints made by teachers. One of the teachers in grade 2 says:

"Many students in grade 2 showing reluctance in doing tasks given in school, lethargic attitude when going to school, even some students easily get angry and refuse directions given by teachers.

Another complaint delivered by homerun teacher in grade 3 is as follow:

"Several students in my class do not understand the benefits of going to school. When they are given homework the rarely finish it. Some of them showing low performance in studying, laziness in doing the tasks, and very dependable on their teachers."

While homerun teacher in grade 1 says:

"Several students in my class also show laziness in going to school and doing their tasks. If they have not been finished in doing their tasks, they put their books into their bags and want to go home immediately."

Based on these three statements we concluded that many students in low grade showing academic burnout. Therefore, we took the low-grade students in SDIT Salsabila Baturrahman Prambanan, Klaten, Central Java as our subjects.

In doing the research we followed the cycle steps in action research. The first step is planning. In the first step, we obtained research subjects (students in grades 1,2, and 3) showing academic burnout indications. We chose these subjects after doing observations and interviews in 2 weeks including achieving the agreement and willingness from parties in school regarding the study.

Based on observation and interview conducted before, we obtained 5 (five) students showing academic burnout indications.

Based on interviews and complaints stated by teachers problems experienced by those 5 students indicate they have academic burnout. This argument also is supported by their study performance. In 
the table showing study performance, there are several blank points because the students did not do their tasks.

We also train teachers and homerun teachers in implementing this group activity to solve academic burnout. The materials delivered in this training are regarding group activity, academic burnout, and game methods in implementing group activity.

The games designed in this study have been adjusted with the purpose of the study (solving academic burnout), such as Picture Puzzle, Continuing Stories, and Throwing the Ball. The procedures of group activity are started by a game and after the game is finished then materials or information regarding academic burnout are delivered by discussing how to solve academic burnout so it can improve students' motivation to go to school (according to the purpose of this study).

In this step, researchers and teachers created a schedule, time, place, and facilities to implement group activity. We decided on the schedule of actions (group activity with games, conducted once in two days for a week). The time was after the second break time (around $1.00 \mathrm{pm}$ ). For places, we adjusted with the games that would be carried out. The second step is action implementation. We implemented group activity through designed and adjusted games with students' conditions in low grade. Actions and results are presented consecutively as follows.

\section{Action I}

In this step, the teacher implements group activity with the Picture Puzzle game. The picture depicts children going to school bypassing several obstacles with high spirits. The procedures of this game are as follows: first, the teacher gives the pieces of the puzzle (but not all of them). Second, we hide a piece of the puzzle, thus students will have difficulty in completing the puzzle. Third, after arranging the puzzle, the students will ask about the missing piece. Forth, we will ask them to discuss how to solve the problem. After the discussion is ended, we show the missing piece so the puzzle can be complete. This game is carried out again once in two days for a week, so the students will understand the procedures of the game. The purpose of this game is to grow motivation in students to go to school, improve concentration, create an active, creative and joyful learning atmosphere, learn to work in a team, and grow confidence in students. The result of this game is summarized in Table 2.

Table 2. Result of Action 1

\begin{tabular}{|c|c|c|c|}
\hline No. & Age (y/o) & Grade & Result \\
\hline 1. & 6 & 1 & $\begin{array}{l}\text { The student can work in a team, in and out of a team without any reason, pay } \\
\text { attention to the instructions given and do the tasks given to the team even if it is } \\
\text { difficult. }\end{array}$ \\
\hline 2. & 8 & 2 & $\begin{array}{l}\text { Student can work with other teams, pay attention to the instructions, play an } \\
\text { active role, give a solution, give ideas, like making noises, do anything to } \\
\text { complete his/her tasks even if he/she cannot complete it and do the task fast. }\end{array}$ \\
\hline 3. & 7 & 2 & $\begin{array}{l}\text { The student can work with other teams, pay attention to the instructions, pay } \\
\text { attention to other interesting objects, be active, do his/her tasks even if they find it } \\
\text { difficult, do the tasks given in group activity more and talk more with his/her } \\
\text { friends. }\end{array}$ \\
\hline 4. & 7 & 2 & $\begin{array}{l}\text { Students pay attention to the instructions, do his/her tasks even if it is difficult and } \\
\text { cannot work in a group. }\end{array}$ \\
\hline 5. & 8 & 3 & $\begin{array}{l}\text { Students can work in a group, pay attention to the instructions, be active, give } \\
\text { solutions, give ideas, do the tasks even if it is difficult, and do the tasks fast. }\end{array}$ \\
\hline
\end{tabular}

Based on the result of action I, we show that subject number 4 cannot work in a team while other subjects can work in a team. It is can be understood since they are from different grades. This result shows that students feel comfortable and happy in following the activity. The objective of the game can be achieved as their attitudes showing happiness in following the subjects in class and promising to go to school excitedly.

\section{Action II}

Before conducting action II, the subjects have shown a positive attitude such as going to school excitedly (no more laziness and late) and studying well in class (pay attention to the subjects explained by teachers). This also is stated by teachers as follow: 
"After the first action was implemented, students showed a better attitude. They came to school excitedly, no more students coming late, and can follow the subjects in class well."

A homerun teacher of grade 2 also has a similar opinion as follow:

"Yes, they showed some changes in attitudes. They showed their smiling faces when going to school, followed the subjects in class well, and no coming late."

In action II they were given a game named Continuing Stories. The procedures of this action are as follows. We asked students to make sitting in a circle. Second, we explained the purpose of this game and gave the story theme that would be created together. Third, we noted the students' stories. The first student or student sitting on the right/left side of the teacher would start his/her story in one sentence. The next student on the right side of him/her would continue the story in one sentence too. Forth, we set the story to be an unfinished story before the last student gave his/her story. The story ended when all students delivered their stories. This game makes all students in the group listen to each other carefully and concentrate. If they do not listen to their friend's story carefully nor concentrate, they will be confused when they have to continue the story. The objectives of this game are to improve their concentration, develop their attitude in paying attention, give communication skills (interpersonal relations). The game is carried out once in two days for a week to make the students understand the rules and procedures. The result of this game is shown in Table 3.

Table 3. Result of Action II

\begin{tabular}{|c|c|c|c|}
\hline No. & Age (y/o) & Grade & Result \\
\hline 1. & 6 & 1 & $\begin{array}{l}\text { Students can work in other groups, pay attention to other subjects, pay attention to } \\
\text { the instructions given by teachers or others, like making noises, and do their tasks } \\
\text { even if they find it difficult. }\end{array}$ \\
\hline 2. & 8 & 2 & $\begin{array}{l}\text { Student can work with other groups, pay attention to the instructions, pay } \\
\text { attention to other objects, be active, ask the teacher, do their tasks even if they } \\
\text { find it difficult and does the task fast. }\end{array}$ \\
\hline 3. & 7 & 2 & $\begin{array}{l}\text { Students can work with other groups, pay attention to the instructions, in and out } \\
\text { from the group without any reason, pay attention to other interesting objects, be } \\
\text { active, like making noises and do the task even if it is difficult. }\end{array}$ \\
\hline 4. & 7 & 2 & $\begin{array}{l}\text { Students can work in a group, pay attention to the instructions, pay attention to } \\
\text { other objects, be active, and do the task even if it is difficult. }\end{array}$ \\
\hline 5. & 8 & 3 & $\begin{array}{l}\text { Students can work in a group, pay attention to the instructions, be active, do the } \\
\text { task even if it is difficult, and perform the task fast. }\end{array}$ \\
\hline
\end{tabular}

Observation result of action II shows a change, such as when Roy in action I could not work in a group but in action II he showed improvement. In action II students also show an active role in the group and can work in a group well. From this result, all five students show excitement when going to school, can work in a group well, feel confident, and can do the tasks fast (no more being lazy).

\section{Action III}

In action II we play Throwing Ball. The procedures of this game are as follows. First, we asked the students to make a big circle then we explained the game. Second, we held the ball to be thrown to one of the students. Third, the student threw the ball to the other student, and the student having the ball said his/her name, nickname, address, and hobby. Forth, the student also threw the ball to the other and did the same as the previous student. After all, students were able to mention their identities then the game was restarted and the ball was given back to the teacher. Fifth, in this turn, the student having the ball would throw the ball to the other student and mention his/her friend's identity standing on his/her right side. Sixth, this activity was conducted repeatedly so all the students had their turn. Any student throwing and catching the ball unwell would be given an agreed sanction. The objectives of this game are to grow motivation in studying, improve concentration, lessen the habit of doing the tasks slowly, and create harmonization in the group. The game is repeated once in two days for a week so the students will understand the rules and procedures.

In this game, we hope that students in the group can know each other more. The main objectives of this game are to make them do their tasks fast and accurately, decrease emotional indications, and improve study performance. 
This game asks the students to be able to catch and throw the ball so their habits in doing the tasks slowly can be lessened. All students are asked to retell the obstacle in memorizing their friends' identities. It is intended to train the students to improve their concentration and grow motivation because the students are not always able to catch and throw the ball accurately. The result if the game is summarized in Table 4.

\section{Table 4. Result of Action III}

\begin{tabular}{cccl}
\hline No. & Age (y/o) & Grade & \multicolumn{1}{c}{ Result } \\
\hline 1. & 6 & 1 & $\begin{array}{l}\text { Students can work in a group, pay attention to the instructions from the teacher or } \\
\text { others, be active, do the task given in a group even if it is difficult, and finish the } \\
\text { task fast. }\end{array}$ \\
2. & 8 & 2 & $\begin{array}{l}\text { Students can work with other groups, pay attention to the instructions, be active, } \\
\text { give solutions, share ideas, do the task even if it is difficult, and do the task fast. }\end{array}$ \\
3. & 7 & 2 & $\begin{array}{l}\text { Students can work with other groups, pay attention to the instructions, pay } \\
\text { attention to other interesting objects, be active, give solutions, and do the task } \\
\text { given even if it is difficult. }\end{array}$ \\
4. & 7 & 2 & $\begin{array}{l}\text { Students can work in a group, pay attention to the instructions, pay attention to } \\
\text { other interesting objects, be active, and do the task given even if it is difficult. } \\
\text { Students can work in a group, pay attention to the instructions, be active, share } \\
\text { ideas, do the task given even if it is difficult, and do the task quickly. }\end{array}$ \\
5. & 8 & 3 &
\end{tabular}

The result in action III shows improvement in five students. They become fast in do their tasks, pay attention to the instructions well, can work in a group, be active in groups, and do their tasks even if it is difficult.

Therefore, the students can follow the subjects in class well, have the motivation to perform better, go to school willingly, can work in a group well, and finish their tasks given by the teachers quickly. The teacher also gave positive feedback as follow:

"The students now show their improvement. They are not being lazy anymore to go to school and do their tasks. And when they are in class they pay attention to the class well and do the tasks given quickly."

Homerun teacher in grade 3 also had a similar opinion:

"Ari now is not lazy anymore in doing his tasks even he finishes it quickly. Before Ari was very lazy in doing his tasks, now he is not dependent on his teachers anymore. Indeed, there are positive changes in Ari."

This feedbacks, show that after given actions three times a week, all five students show positive attitudes. They become excited to go to school and do their tasks.

The third step is observation and monitoring. In this step with collaborators, we observed and monitored the implementation of group activity. We used observation guidelines, field notes, documentation, and interviews. Observation and monitoring were conducted in the process of group activity. The results of observation and monitoring are shown in Table 2, Table 3, and Table 4.

We obtained from observation and monitoring conducted in all three actions, all five students can follow group activity well. It is showed by their attitudes such as paying attention to the instructions given by the researcher, give solutions to the group, share the ideas, can work in a group, and do all the tasks given in the group activity process.

The fourth step is analysis and reflection. We analyzed and reflected all the actions conducted and implemented. Based on observation, field notes, documentation, and interviews we conclude that all five students show positive attitudes. They are no longer being lazy to go to school, do their tasks quickly, show improvement in studying and especially they go to school because of their willingness and not because of other influences or forces (from parents or teachers).

Due to the results obtained, then the research can be stopped and needs no more further action. We stopped the study because the main objective of the study has been achieved (the students go to school because of their willingness and not because of other influences or forces (from parents or teachers). Moreover, they become not easily getting angry, passive, and low self-esteem. 
Jurnal Prima Edukasia, 8 (2), 2020 - 142

Muhammad Nur Wangid, Isti Yuni Purwanti

\section{Discussion}

According to Romlah (2006) group activity in elementary school is a part of attitude education and studied as a subject in class. It aims to build positive attitudes and habits on students so they can develop their potentials. It is proved by a result of an experimental study conducted to investigate the effectiveness of group activity in improving student's attitudes and habits in studying and achieving academic achievement (Hussain Ch, 2006).

This study is an effort to build positive attitudes and habits in going to school such as going to school willingly, nit being lazy in doing the tasks given in school, showing good performance and can work in group or socialize with other students and surroundings (Hurst et al., 2013).

The implementation of group activity in solving academic burnout in elementary school students in SDIT Salsabila Baiturrahman Prambanan, Klaten, Central Java is a success. It is proved by positive changes in attitudes and habits, particularly in a willingness to go to school. The success of this study passes the indicators including indications of the syndrome of emotional exhaustion, depersonalization, and reduced personal accomplishment (Maslach et al., 1996) as follows. First, students do not show the sign of emotional exhaustion by showing high motivation and willingness to go to school and do the tasks given well and quickly. It is possible to be achieved because arising high motivation can be conducted by giving cognitive simulation and changing the situation and environment (Bianchi et al., 2018). This condition is created because the teacher is certain that Picture Puzzle can give much positive cognitive simulation, particularly in the early on the game (Tsouloupas et al., 2010). The implementation of the game condition makes the students feel comfortable without any pressure, thus lessen the indications of the syndrome of emotional exhaustion (Beddoe \& Murphy, 2004).

Second, students do not experience depersonalization showed by their ability to join their friends, work in groups, and care with their environment (Blevins et al., 2012). The continuing story makes the students develop attitudes in paying attention and train their communication skills (interpersonal relations), thus they do not experience depersonalization (Shapiro, 2004).

Third, students do not undergo and have low self-esteem. It is showed by their confidence and intention in giving solutions to their friends through seeking solutions with their friends, sharing their ideas, and being active in the group. This condition can be created because throwing the ball game facilitates the students to improve their concentration, lessen their habit of doing the tasks slowly, and create harmonization in the group. Introduction and understanding of others give stimulation to be closer personally and being helpful (Feeney \& Collins, 2015). The feeling and thoughts of having low selfesteem are changed into the intention to help and be able to be better (Hussein, 2018).

Every child is unique. Thus in this study, we held this assumption, and every child following the group activity is given the chance to develop their potentials (Fazio-Griffith \& Ballard, 2014). The game also is design to be suitable with characteristics of students in low-grade elementary schools. The usage of the game in a group activity is to make students understand the information given by the counselors. (Klimova, 2015). This statement is supported by a result of a study stating that game is an appropriate medium in delivering guidance and counseling towards children (Purwanti, 2009).

The group activity can be implemented in all education levels. Moreover, it also can provide information regarding many aspects, thus the individual can obtain more knowledge to develop their potentials well, as what the objective of guidance and counseling service provides (Robison, 2014).

\section{Conclusion}

Game selection determines the implementation of group activity, proved by selecting the appropriate games with students' characteristics, and the objectives of group activity can solve academic burnout. Building good relations among researchers, teachers, and students during the process of group activity is highly needed. It is proved that the students feel safe and conformable to respond during group activity is conducted. Teacher's skills in delivering group activity also are needed. Thus, students can follow the process well and show positive changes in attitudes and behaviors. It implicates that for the next researches to test other games in developing other aspects in solving academic burnout. It needs to create a situation and environment making it possible for students to be consistent in their positive attitudes, thus they will go to school willingly without any influences and forces. We advise other institutions that implementing group activity to solve academic burnout can be continued for solving various 
Jurnal Prima Edukasia, 8 (2), 2020 - 143

Muhammad Nur Wangid, Isti Yuni Purwanti

obstacles experienced by students through game variation adjusted with the condition of students and schools.

\section{References}

Ahmad, S., Hussain, A., Batool, A., Sittar, K., \& Malik, M. (2016). Play and cognitive development: Formal operational perspective of piaget's theory. Journal of Education and Practice, 7(28), 72-79. https://www.iiste.org/Journals/index.php/JEP/article/view/33557

Beddoe, A. E., \& Murphy, S. O. (2004). Does mindfulness decrease stress and foster empathy among nursing students? Journal of Nursing Education, 43(7), 305-312. https://doi.org/10.3928/01484834-20040701-07

Berg, R. C., Landreth, G. L., \& Fall, K. A. (2018). Group counselling concepts and procedures (6th ed.). Rouledge. https://doi.org/10.4135/9781446214800.n5

Bhagat, V., Haque, M., \& Jaalam, K. (2018). Excessive work pressure in University often hampers motivation of academic staffs to work at their optimal level. Journal of Datta Meghe Institute of Medical Sciences University, 13(4), 220. http://www.journaldmims.com/text.asp?2018/13/4/220/256208

Bianchi, R., Schonfeld, I. S., \& Laurent, E. (2018). Burnout syndrome and depression. In Y.-K. Kim (Ed.), Understanding Depression (pp. 187-202). Springer Singapore. https://doi.org/10.1007/978-981-10-6577-4_14

Blevins, C. A., Weathers, F. W., \& Mason, E. A. (2012). Construct validity of three depersonalization measures in trauma-exposed college students. Journal of Trauma \& Dissociation, 13(5), 539 553. https://doi.org/10.1080/15299732.2012.678470

Çam, Z., \& Ögülmüsş, S. (2019). Çalışma yaşamindan okula: Okul tükenmişliğine yönelik kuramsal yaklaşimlar. Psikiyatride Guncel Yaklasimlar - Current Approaches in Psychiatry, 11(1), 5271. https://doi.org/10.18863/pgy.392556

Cordes, C. L., \& Dougherty, T. W. (1993). A review and an integration of research on job Burnout. Academy of Management Review, 18(4), 621-656. https://doi.org/10.5465/amr.1993.9402210153

Crespi, T. D., Gustafson, A. L., \& Borges, S. M. (2006). Group counseling in the schools. Journal of Applied School Psychology, 22(1), 67-85. https://doi.org/10.1300/J370v22n01_04

El Nokali, N. E., Bachman, H. J., \& Votruba-Drzal, E. (2010). Parent involvement and children's academic and social development in elementary school. Child Development, 81(3), 988-1005. https://doi.org/10.1111/j.1467-8624.2010.01447.x

Fazio-Griffith, L. J., \& Ballard, M. B. (2014). Cognitive behavioral play therapy techniques in schoolbased counseling: assisting students in the development of social skills. American Counseling Association, Knowledge Center, 18, 1-14. https://www.counseling.org/docs/defaultsource/vistas/article_18.pdf?sfvrsn=10

Feeney, B. C., \& Collins, N. L. (2015). New look at social support: A theoretical perspective on thriving through relationships. Personality and Social Psychology Review, 19(2), 113-147. https://doi.org/10.1177/1088868314544222

Hurst, B., Wallace, R., \& Nixon, S. B. (2013). The impact of social interaction on student learning. Reading Horizon: A Journal of Literacy and Language Arts, 52(4), 375-398. https://scholarworks.wmich.edu/reading_horizons/vol52/iss4/5/

Hussain Ch, A. (2006). Effect of guidance services on study attitudes, study habits and academic achievement of secondary school students. Bulletin of Education \& Research, 28(1), 35-45.

Hussein, S. (2018). Work engagement, Burnout and personal accomplishments among social workers: A comparison between those working in children and adults' services in England. Administration and Policy in Mental Health and Mental Health Services Research, 45(6), 911923. https://doi.org/10.1007/s10488-018-0872-z

Klimova, B. F. (2015). Games in the teaching of English. Procedia - Social and Behavioral Sciences, 191, 1157-1160. https://doi.org/10.1016/j.sbspro.2015.04.312 
Lakhani, P. K., Jain, K., \& Chandel, P. K. (2017). School adjustment, motivation and academic achievement among students. International Journal of Research in Social Sciences, 7(10), 333 348. http://www.indianjournals.com/ijor.aspx?target=ijor:ijrss\&volume=7\&issue=10\&article=029

Maslach, C., Jackson, S. E., \& Leiter, M. P. (1996). The Maslach Burnout inventory. In C. P. Zalaquett \& R. J. Wood (Eds.), Evaluating Stress: A Book of Resources (pp. 191-217). The Scarecrow Press.

McNiff, J., \& Whitehead, J. (2011). All you need to know about action research. Sage Publications. https://doi.org/10.1080/14767333.2012.687918

Pingge, H. D., \& Wangid, M. N. (2016). Faktor yang mempengaruhi hasil belajar siswa sekolah dasar di kecamatan Kota Tambolaka. Jurnal JPSD (Jurnal Pendidikan Sekolah Dasar), 2(2), 107122. https://doi.org/10.12928/jpsd.v2i2 24947

Purwanti, I. Y. (2009). Efektivitas program layanan bimbingan kelompok melalui permainan untuk mengatasi kesulitan belajar siswa sekolah dasar (Studi eksperimen terhadap siswa kelas 4 SDIT Salsabila Purworejo Jawa Tengah dan SDIT Salsabila Klaseman Yogyakarta). Universitas Pendidikan Indonesia.

Rahmati, Z. (2015). The study of academic Burnout in students with high and low level of selfefficacy. Procedia - Social and Behavioral Sciences, 171(1996), 49-55. https://doi.org/10.1016/j.sbspro.2015.01.087

Riva, M. T., \& Haub, A. L. (2004). Group counseling in the schools. In Handbook of Group Counseling and Psychotherapy (pp. 309-321). SAGE Publications, Inc. https://doi.org/10.4135/9781452229683.n22

Robison, F. F. (2014). It's a game! Evaluation of a classroom game to enhance learning in an introductory counseling course 1. Innovative Teaching, 3(1), Article 10. https://doi.org/10.2466/07.08.IT.3.10

Romlah, F. (2006). Psikologi belajar Pendidikan Agama Islam. In Ponorogo: STAIN Ponorogo. STAIN Ponorogo.

Shechtman, Z. (2014). Group counseling in the schools. Hellenic Journal of Psychology, 11, 169-183.

Stringer, E. T. (2007). Action research (3rd ed.). SAGE Publications.

Tsouloupas, C. N., Carson, R. L., Matthews, R., Grawitch, M. J., \& Barber, L. K. (2010). Exploring the association between teachers' perceived student misbehaviour and emotional exhaustion: the importance of teacher efficacy beliefs and emotion regulation. Educational Psychology, 30(2), 173-189. https://doi.org/10.1080/01443410903494460

Wakil, K., Qaisar, N., \& Mohammed, C. (2017). Enriching classrooms with technology. European Journal of Open Education and E-Learning Studies, 2(1), 99-108. https://doi.org/10.5281/zenodo.841925

Walburg, V. (2014). Burnout among high school students: A literature review. Children and Youth Services Review, 42(October), 28-33. https://doi.org/10.1016/j.childyouth.2014.03.020

Yang, H.-J. (2004). Factors affecting student burnout and academic achievement in multiple enrollment programs in Taiwan's technical-vocational colleges. International Journal of Educational Development, 24(3), 283-301. https://doi.org/10.1016/j.jjedudev.2003.12.001

Yang, H., \& Chen, J. (2016). Learning perfectionism and learning Burnout in a primary school student sample: A test of a learning-stress mediation model. Journal of Child and Family Studies, 25(1), 345-353. https://doi.org/10.1007/s10826-015-0213-8

Yuen, M. (2008). School counseling: Current international perspectives. Asian Journal of Counselling, 15(2), 103-116. 